teaching of botany in any university in Britain; and as yet there was no journal of the nature of the Annals. But the revival of close observational study in botany under Huxley and Thiselton-Dyer at South Kensington in the early 'seventies, recorded last year by various writers in the New Phytologist, was beginning to take effect in $\mathrm{I} 88 \mathrm{r}$, when the British Association met in York. There the outstanding feature was the address of Hooker on geographical distribution. This and the papers by Bayley Balfour on Socotra and by Baker on Madagascar were all that really mattered botanically, and almost all the contributions were systematic or regional in subject. The revival of the laboratories had not yet fructified.

At this time all the work that was done in laboratories was called 'physiology,' as distinct from systematic botany, which was conducted on dry specimens in the herbarium. In 1887 , six years after the York meeting, the Annals of Botany was founded through the activity of the late Sir Isaac Bayley Balfour, and a small committee of guarantors whose personal security induced the Clarendon Press to make the venture. From the start that journal has paid its way. The forty stately volumes form a record, between the pages of which may be read the history of botanical progress in Britain, and in some degree also in the United States, for American botanists have always been with us in its pages.

In the first issues of the Annals, morphology and systematic botany preponderated, and from the proceedings of the meeting of the British Association in Oxford in 1894 we see that this was still so. That meeting witnessed a crisis in the affairs of botany in Britain. A newly established Section I of Physiology assumed that the functional activities of plants would be swept, together with those of animals, into its hands. Up to this time Section D had been the undivided section of Biology. An irregular cleavage of interests was set up by this claim, for the zoologists were mostly willing to give up their physiology, but the botanists were not. Their refusal to accept divorce of form from function contributed to, or at least coincided with, the foundation of a separate Section $\mathrm{K}$ of Botany, and has dictated the policy of British botany ever since.

As we pass from 1894 to the current period we perceive a marked shifting of the interest of botanists from the study of form to that of the intimate constitution and functional activity of plants. Whole fields of colloidal chemistry and physics, of quantitative physiology, of cytology and genetics, of ecology, of fungology and bacteriology, have been opened up. The present century has been specially marked by the extension of opportunities for physiological research, by better equipment of departments in the universities, and by the foundation of independent establishments carrying on experimental inquiry in its broadest application. This is rapidly bringing the science into closer relation with Imperial and social aims.

It is needless to specify, but the effect of it all is plainly written in the pages of the Annals. Experimental results have gradually taken the preponderant place over description and comparison, as is amply shown in the last January number. 'For better, for worse,' the pendulum has definitely swung over from the extreme systematic position of half a century ago, through a phase of prevalent morphology (or perhaps we should better say of organography), to an extreme physiological position at the present time. Some may even have felt that this address is in itself an anachronism, in that it has not touched upon the moving physiological questions of the day. While I may claim none the less to sympathise with physiological aspirations, I do not assent to any ultra-physiological aspect of botany that would degrade or minimise the comparative study of form. Medio tutissimus ibis is still a true maxim. The laboratory physiologist, dealing with the things of the moment, cannot safely detach himself from the things of the past as recorded in heritable form. Hé should not allow himself to be immersed in statistics and neglect history. The pendulum has gone full swing, within a period of about half a century; but we may confidently anticipate a return towards some middle position.

\title{
Power Alcohol and other Petrol Substitutes.
}

A LTHOUGH opinions differ concerning the extent A of the world's petroleum reserves, it is generally agreed that if the consumption of petrol continues to increase at its present rate, available supplies will soon become inadequate. Thirty years ago, it is said, there were but four motor cars in the United States ; to-day there are nearly twenty million, and the consumption of petrol in that country has risen to about 900 million gallons a month. The demand for aviation shows every sign of expanding, and when we consider that petroleum is very unequally distributed in the earth's crust, and that economic independence is still a watchword in international politics, we can readily understand the vigorous efforts that are being made to produce liquid fuels by artificial means.

So far as we can see to-day, there are not many possible alternatives to petrol. There are, indeed, immense supplies of liquid fuel lying dormant in the oil-shales that are so abundantly distributed over the earth, but until methods of extraction and purification are devised that are both technically and economically successful, we shall continue to look to other fossil fuel, coal or peat, to vegetable matter, and to the mixture of carbon monoxide and hydrogen known as 'water-gas,' to supplement our present supplies of petrol, and to replace them when the day of extinction draws nigh.

Benzol is an excellent motor-fuel, but its production is comparatively small; and it is required for other purposes: for example, for dyes and explosives. Acetone is the ideal liquid for mixing with other motor-fuels, but at present it is too costly to compete with them, although its commercial production through the acetic acid made by fermenting cellulose may be achieved at an early date, and so bring it into the foreground. Alcohol is of especial significance, because the raw materials of its manufacture, cellulose and sugar, are renewed incessantly by a bountiful Nature, and also because its value as a motor-fuel, particularly in admixture, has been proved beyond a doubt. Hydrocarbon

NO. 2968, VOL. II 8 ] 
oils of low boiling-point, such as are produced by 'hydrogenating' coal and peat, or by passing water-gas over heated catalysts, are among the most likely substitutes for petrol; from the technical standpoint the elaboration of such processes will be comparatively easy; the whole issue lies in their economy. Though the raw materials-coal, peat, air, water-are cheap, heavy capital expenditure upon plant appears to be unavoidable, and in some instances a considerable amount of energy has to be expended in promoting the chemical reactions concerned.

Of a different order are the processes for producing alcohols (and acetic acid) from cellulose or sugar by fermentation, for they require neither a high temperature nor a high pressure. Here again the problem is essentially an economic one. The raw material may be very cheap, especially if it grows wild, but it may cost a great deal to collect and transport. A few years ago there was much talk of utilising the Indian mahua flower as a source of power alcohol, but the proposition was soon found to be uneconomic, mainly on account of the cost of collecting the flowers. Cultivated sugarcane and sugar-beet are necessarily more costly than wild vegetation, and they cannot be grown everywhere. Moreover, they contain an essential foodstuff, and the world-price of sugar rules them out as sources of power alcohol unless their production is subsidised by the State. Molasses, being a by-product, is in a different category. Although it is produced in considerable quantity (constituting about 30 per cent. of the weight of raw sugar manufactured), supplies of it would not cover more than a fraction of the world's requirement of light motor-fuel in the event of a petrol famine; its production is confined to sugar-growing countries, and it is in great demand by manufacturers of rum and cattle-cake. The production of fuel-alcohol from molasses is now being undertaken on a large scale in Queensland, Australia, states Dr. W. R. Ormandy (Journ. Soc. Chem. Ind., Aug. 13, 1926), where, with the aid of the Queensland Government, a plant is being erected to produce two million gallons of alcohol per annum, and three additional plants are projected. This enterprise will be assisted by the existence of a thriving sugar industry, and by the total absence of petroleum deposits in Australia.

Among post-War developments the initiation of a State-subsidised beet-sugar industry in Great Britain is one of the most interesting. A flourishing industry of this kind would have far-reaching effects, especially upon agriculture; and the view being held in certain quarters that agriculture would benefit more if beets were grown for the distillery than for the beet-sugar factory, the Government appointed a small committee, consisting of two chemists and one physicist, to inquire into certain economic aspects of the question. The report, ${ }^{1}$ which was issued in July, is a short document of a few thousand words. In reply to the questions put to it, the Committee estimates the cost of raw material per gallon of alcohol (taken throughout as 95 per cent. by volume) to be 5 per cent. of the price per ton of beet, due allowance being made for the value of residual products. Cost of conversion or manu-

1 Power Alcohol Production, being a report to the Minister of Agriculture and Fisheries of the Departmental Committee appointed by him in connexion with the Manufacture of Alcohol for Power Purposes from Sugar Beet. (London: H.M. Stationery Office, 1926.) $6 d$. net. facturing cost is given as $9 d$. per gallon of alcohol, so that, excluding other charges (v.i.), the cost per gallon net naked at works would be $1 s .9 d$. or $2 s .9 d$., according as the price of sugar-beet is taken at $\mathrm{I} l$. or $2 l$. per ton. The yield of alcohol from one cwt. of sucrose is 8 gallons theoretically, 6.8 gallons in practice. With the aid of these figures, and taking $28 \mathrm{~s}$. per cwt. as the commercial price of sugar and Is. $6 d$. or $2 s$. per gallon as the probable price of power alcohol, the Committee calculates that with the same rate of subsidy in both cases (Igs. 6d. per cwt. for sugar and $2 s$. $10 \frac{1}{2} d$. per gallon for alcohol), the subsidy would amount to 70 per cent. of the commercial price of sugar, and I9I or I44 per cent. of the commercial price of alcohol.

The economic case against subsidising the sugar-beet industry for producing power alcohol is really stronger than these figures suggest. The Committee ignores (wittingly) charges for denaturing, packing, transporting, and selling. Assuming a wide distribution, these charges would amount to about Is. per gallon; hence the subsidy would really represent 258 or $22 \mathrm{I}$ per cent. of the commercial price of the alcohol. Furthermore, it must not be overlooked that the present rate of subsidy is very high and will diminish as time goes on. Last season the price paid to English growers was about $56 \mathrm{~s}$. per ton of beet, and the subsidy per ton was about equal to the price received by Dutch growers for their produce ; in other words, the English beet-sugar manufacturers practically obtained their raw material for nothing.

The Committee was also asked to report upon the prospects of producing power-alcohol by synthetic processes. Its reply is to the effect that the present position of such processes is obscure, and that reliable statements of costs will not be available for some time. Nevertheless, a useful appendix is inserted containing remarks on the chief processes that are potentially important for making alcohol and other liquid fuels from sugar, cellulose, coal, and water-gas.

Preparation through ethylene appears unlikely to provide alcohol in quantity, and synthesis from calcium carbide is regarded as improbable in view of the abandonment of carbide manufacture in this country owing to economic considerations. The use of watergas for making liquid fuels, whether alcohols or hydrocarbons, is held to be promising, although but little has been done in this direction in Great Britain. Processes involving the use of high pressures, like those of Patart and Fischer, are referred to, but no specific mention is made of Fischer's work on producing hydrocarbon liquid fuel from water-gas without employing high pressures. In some quarters this development is regarded as a great advance, but it should not be overlooked that the saving effected by dispensing with the costly high-pressure plant is quite counterbalanced by the cost of the very much larger plant required for working with gases at ordinary pressure. A few reasons are given for and against the use of methylalcohol as a motor-fuel, but the Committee issues no verdict on this head. Actually methyl-alcohol is a very inferior fuel, not only because it has a low calorific power, but because it causes serious 'pinking' in the engine. The Committee thinks well of the possibilities of the improved Classen and Prodor processes for converting the cellulose of wood, or waste-wood, into 
sugar and alcohol, especially in countries where wood is abundant. There is, however, little prospect for making alcohol from waste sulphite-liquors in Great Britain, whilst production by fermenting cellulose is more likely to be developed in the overseas dominions than in our own country.

The outlook for producing motor-fuel from coal is considered to be favourable, but not by the lowtemperature carbonisation process, which, the Committee states, cannot yet be worked on a large scale at a profit, and when it can be so worked it would not provide more than a fraction of our requirements in heavy and light fuel-oil. The Bergius process (for the investigation of which the Government has recently granted the sum of $25,000 l$.) is stated to be the only one which could satisfy our requirements, but in view of the difficulty in constructing plant, some years must elapse before really commercial data concerning it can become available. In its remarks upon this process the Committee gives some quantitative data which are not up-to-date. The statement that at least one ton of coal must be burnt for every ton put through the process should read " one ton of coal is burnt as fuel for every two tons put through the process"; and the yield of light fuel is not I 5 gallons but from 20 to 25 gallons per ton, according to the quality of the coal treated. Further, the remark that " 65 per cent. of the weight of the coal may be converted into a kind of oil," would be more accurate in the form: "85"93 per cent. of the coal substance is converted into oil."

In its summary of this interesting section of the report, the Committee states that of all the processes not involving the distillation of fermented foodstuffs, the most likely to be adopted in Great Britain are those based upon the use of water-gas as raw material, and those by which fermentable sugars are obtained in high yield from wood. It is, however, strongly open to doubt whether the latter processes could be worked economically in Britain, where wood is scarce and expensive, and where wood-waste can only be collected and transported at prohibitive cost.

\title{
Discoveries in the Gobi Desert by the American Museum Expeditions. ${ }^{1}$
}

\author{
By Prof. Henry Fairfield Osborn, For. Mem. R.S.
}

T $N$ r 799, William Smith, then a young man of thirty; who was born at Churchill in Oxfordshire, dictated his now classic document, "The Order of the Strata," including a map showing the successive and characteristic fossils of southern Britain and the Oxford clay underlying this great University, with its Jurassic deinosaur Cetiosaurus. In the century and a quarter which has intervened before the present meeting of the British Association in Oxford, the twin sciences of geology and palæontology have reached a degree of precision which enables us, after our relatively brief and intensive surveys of the past four years, to declare 'the order of the strata' of Mongolia. Included in the Gobi Desert is a stratum equivalent in age to the Oxford clay of William Smith, containing the giant sauropod Asiatosaurus, a first cousin of the Oxford Cetiosaurus.

Meanwhile, physicists have extended the life-history period of the earth from the momentary 5000 years of Usher to the I,000,000,000 years of Rutherford. This allows a comfortable margin of 400,000,000 years' time for the wonderful procession of evolutionary advance recorded in the twenty-four chapters of Mongolian prehistory, beginning with the equivalent of the Purbeck and Oxford formations of Upper Jurassic time, continuing with the appearance of man in the Old Stone, Age, ending practically with the dominance of Ghenghis Khan, and followed by the decline of Mongolia to its present desert and relatively uninhabited state.

In the meantime, this now arid 'roof of the world" has been the scene of a whole succession of animal dynasties, fertile, productive, with a relatively temperate and invigorating climate, sometimes arid,

1 From an evening discourse delivered to the British Association at Oxford on August 9. For further information regarding these expeditions reference should be made to "Methods and Results of the American Museum Expeditions in the Gobi Desert, 1922-25" (NATURE, August 7 1926, pp. 198, 199), a lecture delivered to the Geological Society of London, x $926, \mathrm{pp}$. 198,
June $23, \mathrm{x} 926$.

$$
\text { NO. 2968, VOL. I I } 8 \text { ] }
$$

sometimes pluvial, from first to last the homeland of waves of migrating land reptiles and mammals, which successively spread into every other continent (Fig. I). It is a singular fact that this first and greatest of all life-centres (7) of prehistory was the last to be discovered, following by a half to three-quarters of a century the discoveries of great life-centres in Australia, in North and South America, in northern Africa, and in southern Asia. Although each of these great centres contributed its quota to the prehistory of the earth, none played a part at all comparable to that of central Asia.

With this introduction we may proceed to show by means of photography the contrast between the present geography of Mongolia and its palæogeography as recently revealed, and exhibit a new palæogeographic map of the world (Fig. I) prepared especially for this discourse, showing that by placing North America on the east, Asia in the centre, and Europe on the west of an equal-area projection, we have a complete solution of all the animal migratory routes from Upper Jurassic time to the six great waves of human migration which swept over northern Asia into North America in late Pleistocene time.

\section{Present Geography of Mongolia.}

The position of Mongolia in Asia as shown in the map of Perthes may be projected areally on a map of the United States along lines of the 4oth parallel; and there at once appears the remarkable similarity between the Mongolian fauna and that of the Rocky Mountain region throughout the entire period from Jurassic to recent times, the parallelism varying in closeness from epoch to epoch, at times Europe being closer than the United States. To the north of the hypothetical 'Gobia' lies 'Angara,' to the south the 'Gondwana' of Suess. 